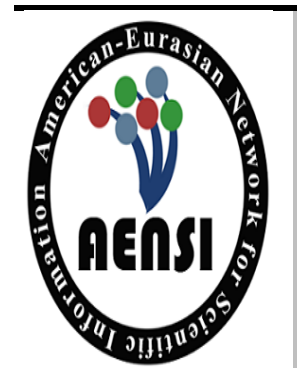

AUSTRALIAN JOURNAL OF BASIC AND APPLIED SCIENCES

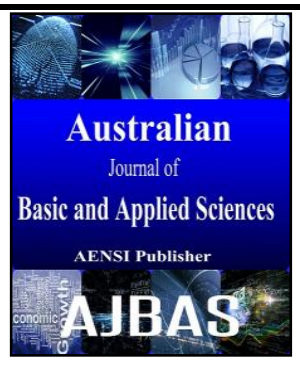

\title{
Spectroradiometry from Eucalyptus grandis W. Hill ex Maiden population with different ages
}

\author{
${ }^{1,2}$ Ana Herrera, ${ }^{2}$ Natalia Lima, ${ }^{2}$ Izabela Silva, ${ }^{2}$ Renann Oliveira, ${ }^{3}$ Emanuel Silva, ${ }^{4}$ Gabriel Marangon, ${ }^{5}$ Rudiney Pereira \\ ${ }^{I}$ Departament of Agricultural Research, National Experimental University of Táchira, San Cristóbal, Venezuela. \\ ${ }^{2}$ Department of Animal Science, Integrated Doctoral Program in Animal Science/University Rural of Pernambuco (UFRPE) - Federal \\ University of Paraiba - Federal University of Ceará, Recife - PE, Brazil. \\ ${ }^{3}$ Department of Forestry Science - UFRPE, Recife - PE, Brazil. \\ ${ }^{4}$ Center of Agricultural Sciences, Federal University of Alagoas, Rio Largo - AL, Brazil. \\ ${ }^{5}$ Center of Rural Sciences, Federal University of Santa Maria, Santa Maria - RS, Brazil.
}

\author{
Address For Correspondence: \\ Ana Herrera, Department of Animal Science, UFRPE. Rua Dom Manoel de Medeiros, s/n, Dois Irmãos, 52171-900. Recife. Brazil. \\ Email: anamariaherreraangulo@yahoo.com
}

\section{A R T ICLE INFO}

Article history:

Received 12 October 2017

Accepted 22 December 2017

Available online 31 December 2017

Keywords:

eucalyptus, reflectance, remote sensing.

\begin{abstract}
A B S T RA C T
BACKGROUND: Studies about remote sensing have been performed approaching the object response to radiation, in which soil and vegetation are most investigated in agricultural science. OBJECTIVE: This study aimed to compare reflectance levels from Eucalyptus grandis Hill ex Maiden leaves through spectral measures in population with two ages. MATERIAL AND METHODS: Trial was carried out at FEPAGRO experimental plot, located in Santa Maria - RS. Experimental design was completely randomized with population in two ages as treatment (44 and $20 \mathrm{mo}$ ) in which were evaluated in North, Center, East, West and South direction. The FieldSpec $® 3$ spectrophotometer was used to estimate the reflected radiance from adaxial surface of leaves in three spectra, visible spectrum (VS, 400-700 $\mu \mathrm{m}$ ), near infrared (NIR, 700$1000 \mu \mathrm{m}$ ) and mid infrared (MIR, 1000-1250 $\mu \mathrm{m}$ ). Kruskall-Wallis test was applied using R statistical software. RESULTS: For VS, in $550 \mu \mathrm{m}$ was observed a reflectance peak associated to total chlorophyll content of leaf, in which the 44-mo population had the highest peak. For NIR and MIR, the Center, North and West directions had the greatest leaf reflectance in 44-mo population. Reflectance tends to the same response through the wavelength of VS, NIR and MIR. CONCLUSION: The response of VS from Eucalyptus grandis Hill ex Maiden leaves is different regarding the plant age and different directions of sample collection. The NIR and MIR spectrum have no reflectance standard response regarding the population ages.
\end{abstract}

\section{INTRODUCTION}

The way as a vegetation are covering a specific area or land has been studied over years, under different point of view, and distributed along several field science as taxonomy, physiology, botany, etc. When humans discovered that plants use electromagnetic radiation as energy supply to grow through photosynthesis, that relation is a target for detailed studies, in which remote sensing is one of the field sciences that undergoes to analyze the way as a vegetation process electromagnetic radiation (Jensen, 2009). According to Lippert et al. (2014) variety of materials can be analyzed in different ranges of the electromagnetic spectrum, considering that each material has specific characteristics according to each radiation range.

Thus, remote sensing plays an important role for geographic data input and analysis, and can facilitate the comprehension of studies regard to electromagnetic radiation, as well as other environmental research (Ferreira et al., 2008). Even Earth surface layer suffers interaction with electromagnetic radiation and, depending on physical, chemical and biological properties of targets occur that energy fractionation (Moreira, 2011).

Open Access Journal

Published BY AENSI Publication

(C) 2017 AENSI Publisher All rights reserved

This work is licensed under the Creative Commons Attribution International License (CC BY).

http://creativecommons.org/licenses/by/4.0/

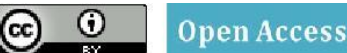

To Cite This Article: Ana Herrera, Natalia Lima, Izabela Bonifacio, Renann Oliveira, Emanuel Silva, Gabriel Marangon, Rudiney Pereira, Spectroradiometry from Eucalyptus grandis W. Hill ex Maiden population with different ages. Aust. J. Basic \& Appl. Sci., 11(15): 47-53, 2017 
On vegetation, the energy fractionation depends on electromagnetic spectrum region, where in leaves occur a greater solar radiation interaction. Then, the spectral responses of leaves in a specific vegetation have interference as genetic as by direction. Measuring reflectance levels on vegetation, specifically on leaves, can promote a curve of spectral for a specific vegetation, providing knowledge about forestry species reflectance of agronomic interest (Moreira, 2007; Silva et al., 2012).

One of the way to measure the vegetation reflectance is by spectroradiometry technique, which is based on knowledge how each object of interest respond to phenomena of electromagnetic energy split: absorption, emission and reflection (Jensen, 2009; Ponzoni and Shimabukuro, 2009).

Eucalyptus genus had an expressive production increase last decades, and due to it was detached on world scenery including sustainability bias. The specie Eucalyptus grandis plays a great economic role as consequence of its rapid growth, productivity, adaptation capacity and multiple use, for example to produce farm, cellulose, or lamination and packing case shop (Gabriel et al., 2013).

Our objective in this study was to evaluate different reflectance levels from Eucalyptus grandis W. Hill ex Maiden tree leaves using spectral measures on plant population of different ages. Besides, we intended to infer the greatest period in order to differentiate and emphasize the importance of studying natural variation of reflectance curve for this forestry specie.

\section{MATERIAL AND METHODS}

\section{Area of study:}

The experiment was carried out at experimental area of FEPAGRO FLORESTAS - State Agricultural Research Foundation, Forestry Research Centre, located in Santa Maria, Central Depression physiographic region, Rio Grande do Sul, Brazil. The Research Center is located at 29 $40^{\prime} 31^{\prime}$ 'S and $53^{\circ} 54^{\prime} 45^{\prime \prime}$ W geographic coordinates regard to Greenwich, 130-m altitude.

The climate is classified as Cfa type, denoted by $19^{\circ} \mathrm{C}$ annual mean temperature, $1,769 \mathrm{~mm}$ annual mean rainfall and $82 \%$ relative humidity according to Köppen (Moreno, 1961). The natural vegetation is predominant Campos, represented by native vegetation with gallery development over water stream (Abrão et al., 1988). Soil is classified as argisol red-yellow dystrophic arenic (Silva et al., 2006).

\section{Experimental design:}

The experimental design was completely randomized and treatment consisted in two eucalyptus forestry area, where area 1 was composed by Eucalyptus grandis W. Hill ex Maiden population with 44 months aged and area 2 composed by Eucalyptus grandis W. Hill ex Maiden population with 20 months aged.

For area 1, two dominant trees were sampled in north, south, east, west and center direction, summing 10 trees. For area 2, a sole dominant tree were sampled in each direction and population plot, summing 20 trees by block.

Plant sample collection was analyzed using the FieldSpec®3 spectroradiometer at Remote Sensing Laboratory - CCR - UFSM. Reading procedure using the equipment started one hour after plant sample collection. That spectroradiometer performs irradiation and solar radiance measures, can be used on field and laboratory, records from 350 to $2500 \mu \mathrm{m}$ electromagnetic spectrum, as well as has a $10 \mu \mathrm{m}$ spectral resolution and capacity to collect up to 10 spectra by seconds. Data recorded from the procedure comprised wavelength and reflectance ranging from 400 to $1,250 \mu \mathrm{m}$ amplitude split in three bands namely visible spectrum (400-700 $\mu \mathrm{m})$, near infrared $(700-1000 \mu \mathrm{m})$ and mid infrared $(1000-1250 \mu \mathrm{m})$.

\section{Statistical analysis:}

Will-Shapiro and Levene tests were applied to data recorded regarding different treatments in order to verify the normality and homoscedastic (Ott and Longnecker, 2010). Data had no normality and homoscedastic, even after transformation, then, data were submitted to non-parametric test (Kruskal-Wallis) for each spectrum regarding variation sources described above. Statistical analysis were performed by R software, version 2.0.

\section{RESULTS AND DISCUSSION}

The reflectance in visible spectrum for east, north, west and south directions were greater $(\mathrm{P}<0.01)$ in population aged 44 month. Trees aged 20 months had greater reflectance only in north direction (Table 1).

Observed difference between populations could be associated to proportion of leaf pigment, and mainly to chlorophyll content accumulated on leaf sampled. According to Ponzoni et al. (2015), pigments present in leaf, with great proportion of chlorophyll, define the reflectance in that spectrum band. Furthermore, in each band of the electromagnetic spectrum the electromagnetic radiation interacts with the vegetation in a different way, being the leaves the part of greater contribution for the reflection to be detected by the sensors (Brandelero $e t$ al., 2012). 
Table 1: Reflectance $(\rho)$ on visible spectrum $(400-700 \mu \mathrm{m})$ in eucalyptus population with different ages and directions.

\begin{tabular}{|c|c|c|c|}
\hline \multirow{2}{*}{ Direction } & 44 & 20 & \multirow{2}{*}{ P-Value } \\
\cline { 2 - 4 } & $0.063 \pm 0.014$ & $0.067 \pm 0.030$ & 0.001 \\
\hline Center & $0.064 \pm 0.014$ & $0.058 \pm 0.011$ & 0.000 \\
\hline East & $0.072 \pm 0.018$ & $0.064 \pm 0.017$ & 0.000 \\
\hline North & $0.066 \pm 0.015$ & $0.063 \pm 0.014$ & 0.012 \\
\hline Sest & $0.068 \pm 0.018$ & $0.063 \pm 0.012$ & 0.020 \\
\hline
\end{tabular}

Associate the sward with a response is not possible due to the spectrum reflectance had been detected from isolated healthy leaves. Then, leaves from young trees could synthetize greater chlorophyll amount able to absorb large quantity of radiant energy. Similar response was reported by Goergen et al. (2016) that sampled Eucalyptus urograndis aged 3 and 5 years.

Regarding the reflectance response on visible spectrum band, independent of direction (north, center, east, west and south), a similar trend is observed about both populations ages (Figure 1). The blue spectrum ( 450 $\mu \mathrm{m})$ had the lowest reflectance, and the peak was on green spectrum nearby $550-\mu \mathrm{m}$ wavelength with reflectance varying from 8 to $11 \%$. This response can be associated with total chlorophyll present in leaf (Schepers et al., 1996). The highest peaks were reached for north, west and south directions.

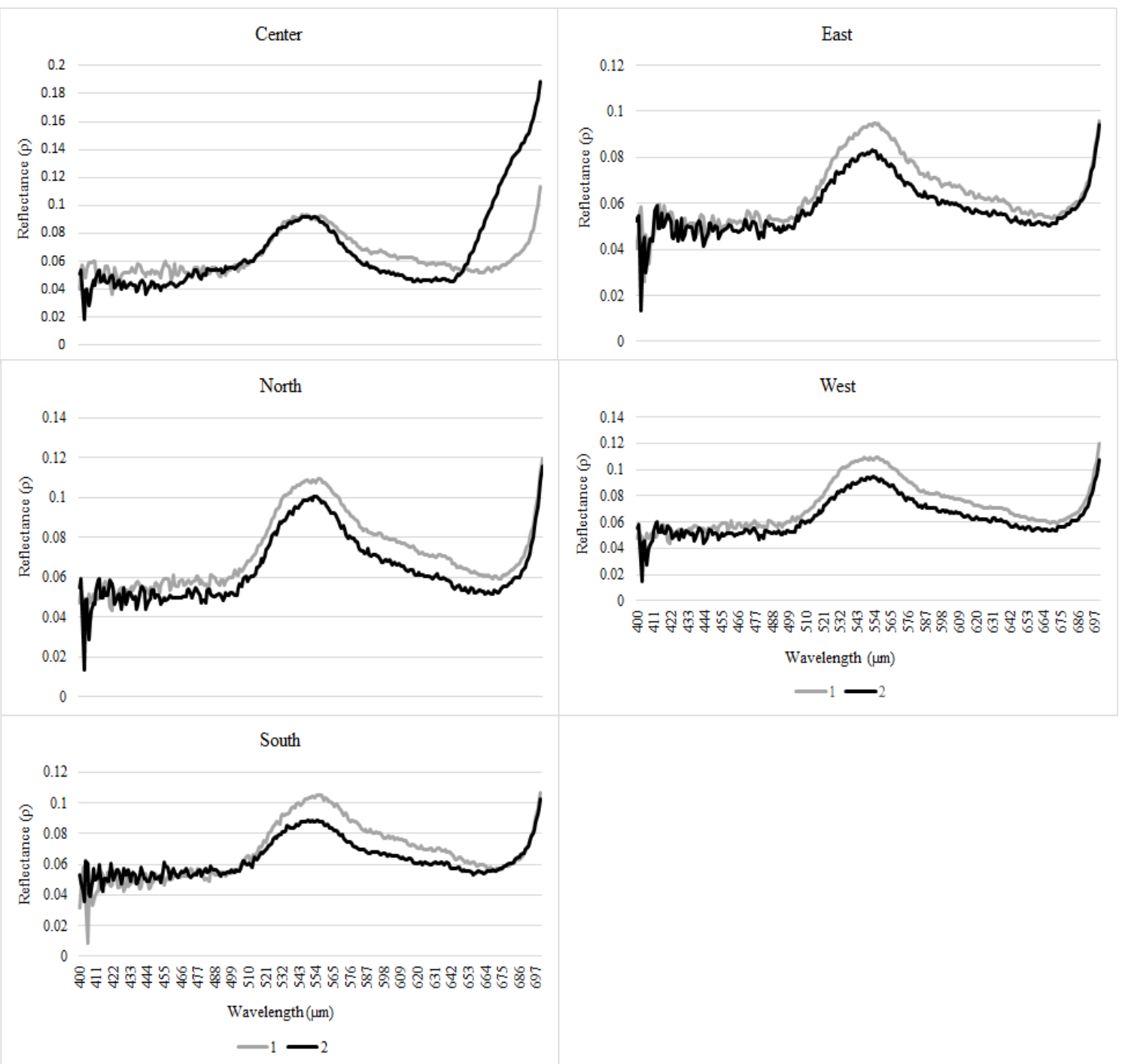

Fig. 1: Reflectance $(\rho)$ regarding wavelength from 400 to $700 \mu \mathrm{m}$, in Eucalyptus population, with different ages (1= 44 months; $2=20$ months) and directions 
In the visible spectrum end, comprising $650-\mu \mathrm{m}$ wavelength, there was another reflectance increase which went over near infrared. Similar responses were observed by other authors studying Eucalyptus (Silva et al., 2012), and other species (Jensen et al., 2009; Hunt Jr. et al., 2013; Jiménez-López et al., 2015).

For near infrared spectrum, greater reflectance $(\mathrm{P}>0.01)$ was recorded from center, north and west directions for populations aged 44 months, and from east and south for populations aged 20 months (Table 2). In that band, the structure of a healthy green leaf is related to reflectance (Ponzoni et al., 2015), regarding that structural characteristics, mostly mesophyll cells, can vary in function of plant growth conditions, intra and interspecies (Hunt Jr. et al., 2011).

The leaves selected to analyze different directions had cell structure heterogeneous in function of age, which was reflected on variability of populations response.

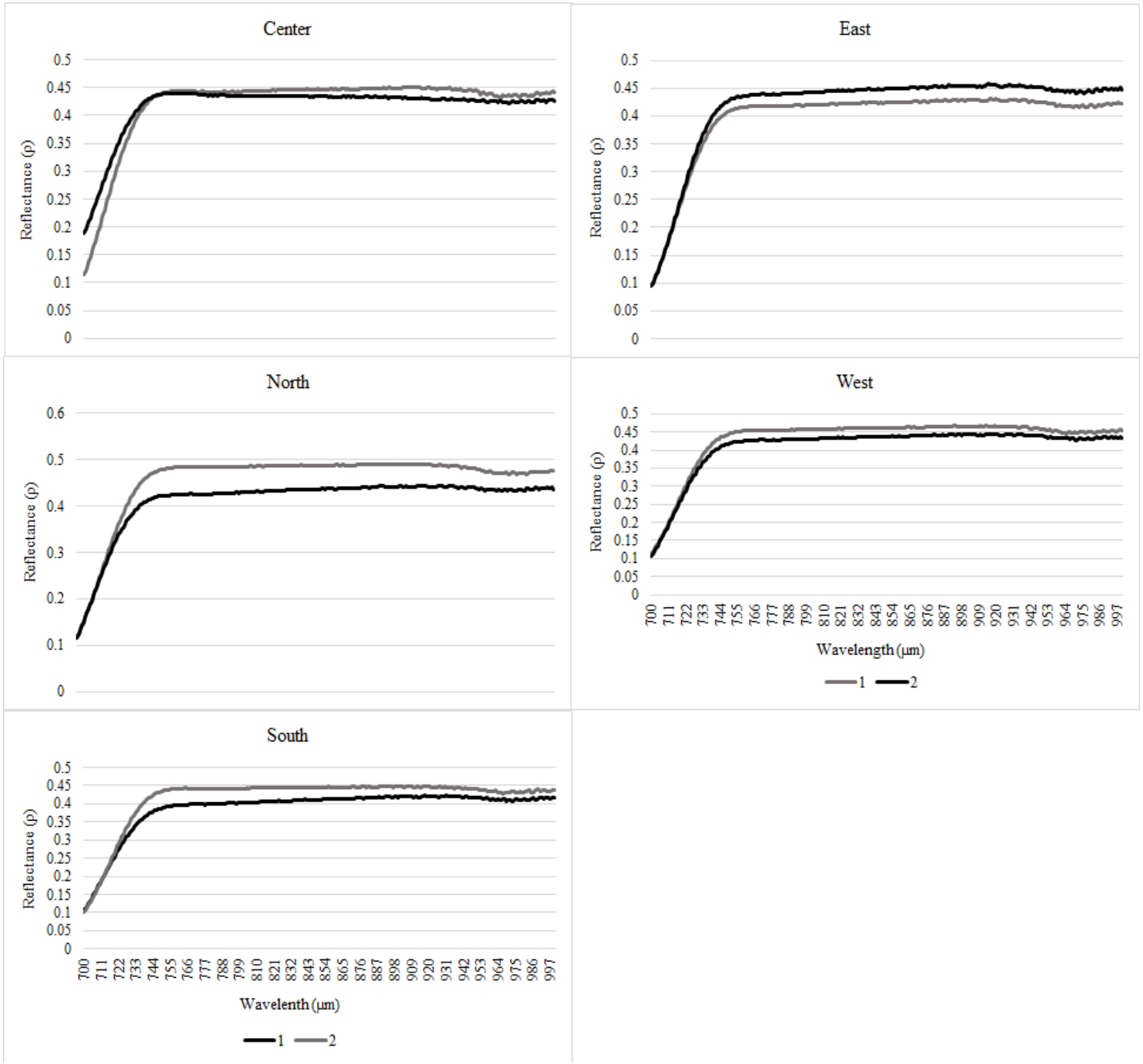

Fig. 2: Reflectance $(\rho)$ regarding wavelength from 700 to $1000 \mu \mathrm{m}$, in Eucalyptus population with different ages (1=44 months; $2=20$ months) and directions.

Table 2: Reflectance $(\rho)$ on near infrared spectrum $(700-1000 \mu \mathrm{m})$ in eucalyptus population with different ages and directions.

\begin{tabular}{|c|c|c|c|}
\hline \multirow{2}{*}{ Direction } & \multicolumn{3}{|c|}{ Age (months) } \\
\cline { 2 - 4 } & 44 & 20 & \multirow{2}{*}{ P value } \\
\hline Center & $0.422 \pm 0.065$ & $0.418 \pm 0.046$ & 0.000 \\
\hline East & $0.398 \pm 0.068$ & $0.420 \pm 0.075$ & 0.000 \\
\hline North & $0.458 \pm 0.075$ & $0.413 \pm 0.063$ & 0.000 \\
\hline West & $0.433 \pm 0.072$ & $0.411 \pm 0.068$ & 0.000 \\
\hline South & $0.388 \pm 0.063$ & $0.418 \pm 0.071$ & 0.000 \\
\hline
\end{tabular}


Considering the near infrared spectrum, the population response was homogeneous for different directions (Figure 2), with reflectance ranging from 40 to $50 \%$ in which the north direction had the highest. This response was constant from about 740- $\mu \mathrm{m}$ wavelength over band.

In function of cell structure of a healthy leaf, the spreading of inner incident radiation keep this condition until reach the mid infrared band, where a reflexing phenomenon is associated to leaf water content (Ponzoni et $a l ., 2015)$. The spectrum trend of our study was similar to reported by other authors who evaluated eucalyptus as well (Silva et al., 2012).

For mid infrared, the greatest reflectance $(\mathrm{P}>0.01)$ was observed for population aged 44 months in center, north and west direction, which had similar response compared to near infrared (Table 3). That spectrum features large absorption, mostly by green leaf water, observing typical peaks of vegetation studied (Carter, 1991; Ponzoni et al., 2012; Jimenez-López et al., 2015).

The population response over mid infrared wavelength spectrum had a similar trend, however, the ages were not uniforms regarding different directions (Figure 3).

Table 3: Reflectance $(\rho)$ on mid infrared spectrum $(1000-1250 \mu \mathrm{m})$ in eucalyptus population with different ages and directions.

\begin{tabular}{|c|c|c|c|}
\hline & \multicolumn{2}{|c|}{ Age (months) } & \multirow{2}{*}{ P value } \\
\cline { 2 - 4 } & 44 & $0.421 \pm 0.009$ & 0.000 \\
\hline Center & $0.436 \pm 0.018$ & $0.449 \pm 0.016$ & 0.000 \\
\hline East & $0.422 \pm 0.016$ & $0.439 \pm 0.012$ & 0.000 \\
\hline North & $0.468 \pm 0.023$ & $0.435 \pm 0.017$ & 0.000 \\
\hline Sest & $0.449 \pm 0.023$ & $0.436 \pm 0.019$ & 0.000 \\
\hline
\end{tabular}
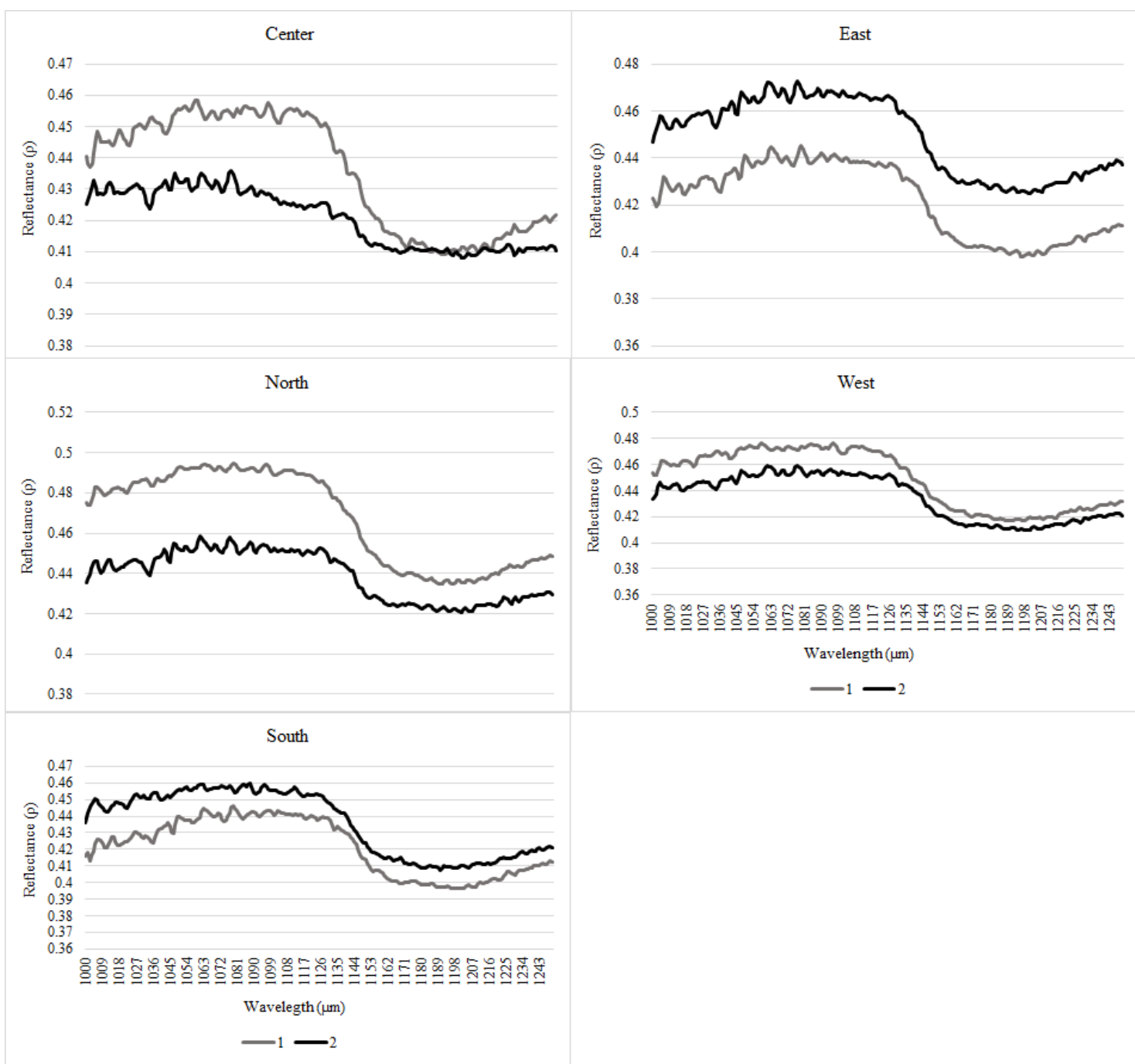

Fig. 3: Reflectance $(\rho)$ regarding wavelength from 1000 to $1250 \mu \mathrm{m}$, in Eucalyptus population with different ages $(1=44$ months; $2=20$ months $)$ and directions. 
Among about 1000 and $1135 \mu \mathrm{m}$, there was a greater reflectance with band among 42 and 49.5\%, in which north direction had the highest value with regard to population aged 44 months. In this band, denoted differences among plant species can be noticed, however, those differences intraspecie are related to plant age, lack of nutrient or plant disease (Pedrali et al., 2016).

\section{Conclusions:}

Reflectance keeps the same trend through the wavelength of visible, near infrared and mid infrared spectra. The visible spectrum response from Eucalyptus grandis Hill ex Maiden leaves is different with regard to plant age and directions sampled. The near and mid infrared band have no reflectance standard response with regard to plant population age. About the near infrared spectrum, the direction should be concerned as a factor when evaluating populations aged differently due to variability observed.

\section{REFERENCES}

Abrão, P.U.R., D. Gianlupi, M.A.D. Azolin, 1988. Levantamento semidetalhado dos solos da estação experimental de silvicultura de Santa Maria. IPRNR., 21: 1-78.

Brandelero, C., E.F. Berra, K.S. Backes, R.S. Pereira, E.J. Brun, 2012. Espectrorradiometria na região do visível e do infravermelho próximo em povoamento de Eucalyptus grandis Hill ex Maiden. Ciência Florestal, 22(1): 215-222.

Carter, G.A., 1991. Primary and secondary effects of water content on the spectral reflectance of leaves. American Journal of Botany, 78(7): 916-921.

Ferreira, L.G., N.C. Ferreira, M.E. Ferreira, 2008. Sensoriamento remoto da vegetação: evolução e estado da arte. Acta Scientiarum. Biological Sciences, 30(4): 379-390.

Gabriel, VA., A.A. Vasconcelos, E.F. Lima, E.F. Cassola, K.D.B. Barreto, M.C. Brito, 2013. A importância das plantações de eucalipto na conservação da biodiversidade. Pesquisa Florestal Brasileira, 33(74): $203-213$.

Goergen, L.C.G., R.V. Kilca, I.S. Narvaes, M.N. Silva, E.A. Silva, R.S. Pereira, M. Adam, 2016. Distinção de espécies de eucalipto de diferentes idades por meio de imagens TM/Landsat 5. Pesquisa Agropecuaria Brassileira, 51(1): 53-60.

Hunt Jr., E.R., P.C. Doraiswamya, J.E. Mcmurtreya, C.S.T. Daughtrya, E.M. Perry, B. Akhmedov, 2013. A visible band index for remote sensing leaf chlorophyll content at the canopy scale. International Journal of Applied Earth Observation and Geoinformation, 21: 103-112.

Jensen, J.R., 2009. Sensoriamento remoto do ambiente: uma perspectiva em recursos terrestres. São José dos Campos. Parêntese Editora.

Jiménez-López, A.F., F.R. Jiménez-López, M. Jiménez-López, 2015. Análisis multiespectral de la vegetación para aplicaciones de sensado remoto. ITECKNE., 12(2): 156-167.

Lippert, D.B., A.C.P. Benedetti, M.M.C. Nunes, L.A. Kervald, M.S. Schuh, R.S. Pereira, 2014. Spectroradiometry of commercial wood veneers in the visible and near infrared spectra. Floresta., 44(1): 125 132.

Moreira, M.A., 2007. Fundamentos do sensoriamento remoto e metodologias de aplicação. 3ra. Ed. Viçosa/MG: Editora UFV.

Moreira, M.A., 2011. Fundamentos do Sensoriamento Remoto e Metodologias de Aplicação. 4 Ed. atualizada e ampliada, Viçosa/MG: Editora UFV.

Moreno, J.A., 1961. Clima do Rio Grande do Sul. Porto Alegre: Secretaria da Agricultura.

Ott, R.L., M. Longnecker, 2010. An introduction to statistical methods and data analysis. Sixth Edition, California, Duxbury press.

Pedrali, L.D., J. Marchesan, T.B. Queiroz, T. Baldin, R.S. Sousa, F.J. Batista, R.S. Pereira, 2016. Comportamento espectral de espécies utilizadas em arborização urbana. Ecologia e Nutrição Florestal, 4(1): 1932.

Ponzoni, F.J., B.E. Shimabukuro, T.R. Kuplich, 2012. Sensoriamento Remoto da Vegetação. 2 Ed., atualizada e ampliada São Paulo, Brasil: Oficina de textos.

Ponzoni, F.J., Y.E. Shimabukuro, 2009. Sensoriamento remoto no estudo da vegetação. São Jose dos Campos: Editora Parêntese.

Schepers, J.S., M.T. Blackmer, W. Wilhelm, M. Resende, 1996. Transmittance and reflectance measurements of corn leaves from plants with different nitrogen and water supply. Journal Plant Physiological, 148: 523 - 529.

Silva, A.B., A.C.S. Silva, A.A.A. Menezes, C.M.L. Mello, 2006. Zoneamento Agroecológico de Pernambuco. Embrapa Solos - Unidade de Execução de Pesquisa e Desenvolvimento-UEP, Recife: Governo do Estado de Pernambuco (Secretaria de Produção Rural e Reforma Agrária). Embrapa Solos. Disponível em: http://www.uep.cnps.embrapa.br/solos/index. 
Silva, E.A., G.P. Marangon, L. Dessbesell, W.W. Morais, D.B. Lippert, R.S. Pereira, 2012. Caracterização espectral na reflectância de Eucalyptus grandis. Floresta, 42(2): 285-292. 